University for Business and Technology in Kosovo

UBT Knowledge Center

UBT International Conference

2012 UBT International Conference

Nov 2nd, 9:00 AM - Nov 3rd, 5:00 PM

\title{
Nanotechnology and his effects in medicine
}

Hatixhe Bilibashi

University of Vitrina

Follow this and additional works at: https://knowledgecenter.ubt-uni.net/conference

Part of the Computer Sciences Commons, and the Engineering Commons

\section{Recommended Citation}

Bilibashi, Hatixhe, "Nanotechnology and his effects in medicine" (2012). UBT International Conference. 72. https://knowledgecenter.ubt-uni.net/conference/2012/all-events/72

This Event is brought to you for free and open access by the Publication and Journals at UBT Knowledge Center. It has been accepted for inclusion in UBT International Conference by an authorized administrator of UBT Knowledge Center. For more information, please contact knowledge.center@ubt-uni.net. 


\title{
Nanotechnology and his effects in medicine
}

\author{
MSc. Hatixhe BILIBASHI \\ University of Vitrina \\ Faculty of Engineering
}

Nanotechnology is a great revolution in the field of information technology that has effects on almost every aspect of the human society nowadays.

It is one of the technologies with huge potentials in many directions. Nanotechnology can be defined as the manipulation, precision-placement, modeling and manufacture of material at the nanometer scale (One meter consists of 1 billion nanometers) (10 $\rrbracket^{\wedge}(-9)$ of a meter). ).Therefore nanotechnology can help save the lives of many people.

Main fields in medicine where nanotechnology can be found are the control and prevention of cancer, diagnostication of the drug dependance, diagnostication of the diabetes, heart diseases and their diagnostification throught the their censors and the MEMS-

Microelectromechanical Systems, of the nanosystems and the nanodevices. Part of the nanotechnology are the nanobots that give the opurtunity to be self diagnosticated. This is a very promising even because is in its early years of usage. A lot of devices of nanotechnology are expected to have a huge positive influence in human being health. It is strongly recomended the usage of these products in medicine and on the other hand further researches should be pursued. 